\title{
ملامح الاتجاه الفقهي في كتاب (تفسير الأحكام) ل لأستاذ عبد الحليم حسن
}

\section{Sutrisno Hadi}

Dosen Tafsir Ahkam UIN Raden Fatah Palembang

Email: sutrisnohadi@ radenfatah.ac.id

$$
\begin{aligned}
& \text { ملخص } \\
& \text { يعد الأستاذ عبد الحليم حسن (19.9-1979 197) من المفسرين الذين لهم دور بارز في تثقيف } \\
& \text { الأمة بسومطرة الشمالية خاصة وإندونيسيا عامة، وقد أثرت خلفيته الدراسية وتفاعله بالأفكار }
\end{aligned}
$$

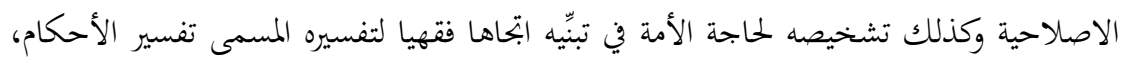

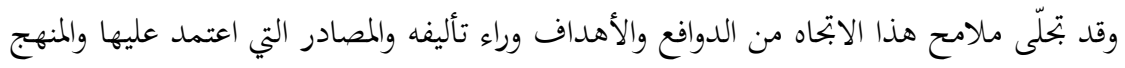

$$
\begin{aligned}
& \text { الذي سار عليه وبالنظر إلى وشرحه لمعاني آيات القرآن، وملامح الاتحاه الفقهي في هذا التفسير }
\end{aligned}
$$

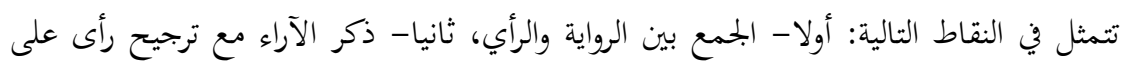

$$
\begin{aligned}
& \text { الآخر، و هذا الترجيح قد يكون بصيغة التصريح وقد يكون بالتلميح، ثالثا- ذكر الآراء المتعددة لترديح }
\end{aligned}
$$

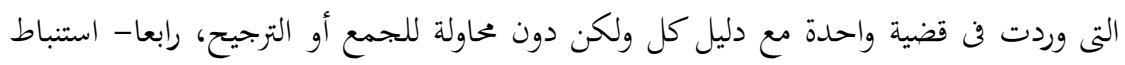

$$
\begin{aligned}
& \text { بعض الأحكام التى تؤخذ من الآية المفسرة. } \\
& \text { الكلمات الرئيسية: الاتحاه الفقهي، عبد الحليم حسن، تفسير الأحكام، }
\end{aligned}
$$

\begin{abstract}
Abdul Halim Hasan (1901-1969 AD) is one of the exegetes (mufassirin) that had a prominent role in educating ummah, especially in North Sumatera and generally in Indonesia. His background of study and interaction with ideas of reform as well as his diagnosis of the people's need have influenced him to adopt the yurisprudence pattern in his book named Tafseer al-Ahkaam, The features of this pattern has been manifested in the background and purpose of the book, references used, methodology used, and his interpretation of the verses. The features of the yurisprudence pattern in this book are manifested in the following points: First: Combining between riwaayah and mind opinion ( $r a$ 'yi), Second: stated views with weighting one of the others, and this weighting may be by implicit statement or hint, Third: stated multiple opinion in one case with prove of each opinions but without trying to collect or weighting, Fourth: Eduction the rules or yurisprudences from the explained verses.
\end{abstract}


Jurnal Ulunnuha Vol.7 No.2/Desember 2018

Keywords: Yurisprudence pattern, Abdul Halim Hasan, Tafseer al-Ahkaam

فمـن هـــا المنطلـق اهـتم المســلمون منـــ

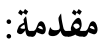

عهد الرعيل الأول بآيات الأحكام، وبرز في كل

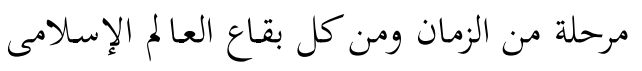

العلماء الذين اعتنوا بها اعتناء خاصا يستنبطون

منها القواعد والأصول ويهاولون اكتشاف الثروة

التشـريعية فيهـا، فمثل هـذا الابتــاه في تفسـير

القرآن هو الذى يسمى بالاتحاه الفقهي.

سمات التفسير الفقهي عبر القرون

ومن سمات الاتجـاه أو التفسير الفقهي

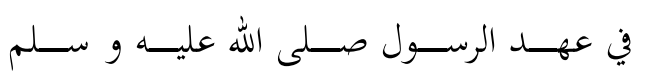

والصحابة عـدم نشوب الخلافـات الفقهية كثيرا

نظرا لفهمهم لما تحمله هذه الآيات من الأحكام

بمقتضى سـليقتهم العربيـة ورجـوعهم إلى رسـول

الله صلى الله عليه و سلم مباشـرة كلما أشكل

عليهم مس ذلك شيئ، فضـال عن كون الأمور

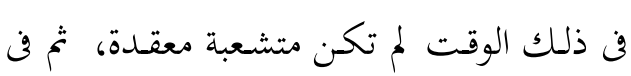

حسين نشـوب الاخـتلاف بيـنهم في حكــم مـن

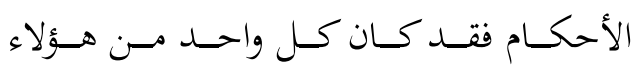

الصحابة المختلفين يطلب الحقق وحده، ومسن ثم

فإن ظهر له أن الحق في جانب مَن خالفه رجع

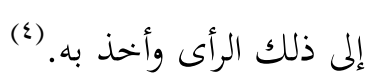

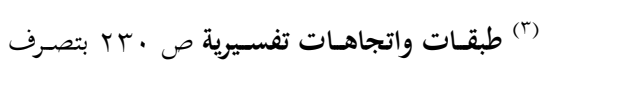

يسير

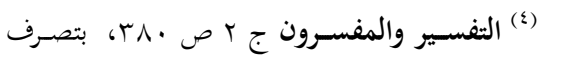

كــان مـن الطبيعـي أن يظهـر الاتجــاه

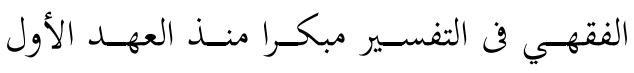

للإسـالام، فـالقرآن الكـيم نـزل بآيـات تتضـمن

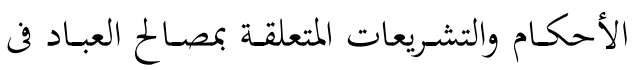

دنيـاهم وآخـرقم، فهـذه الأحكـام تـنظم كافـة

جوانــب حيـاتم علـى مســتوييها- الفــردى

والاجتمــاعى- بتـوازن رائـع باعتبارهـــا ضــرورة

بشـرية، (1) ثم إن البشـرية قـــ عرفـت علـى مـر

التـاريخ أنواعـا متعـددة مـن النظريـات والمنـاهج والنظم والتشريعات التى تستهدف إيجاد سعادة

الفرد في بحتمع فاضل، ولكن لم يبلغ واحد منها إلى ما يبلغه القرآن في التأثير والروعة والإجالال،

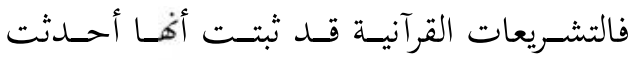

انقلابا عظيما وثورة جذرية ليس فقط فن حياة العرب ولكن في حيـاة البشرية جمعاء على مـر

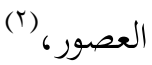

(1) وذلك لأن الإنسان مدلن بالطبع، فهو بحاجة إلى

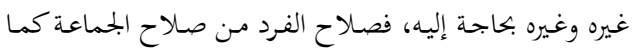

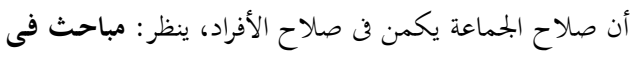

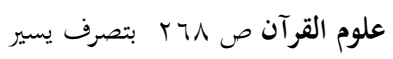
(r)

فضل حسن عباس، (رسالة الدكتوراه في قسم التفسير) كلية

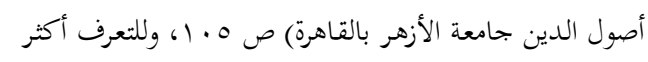
على وجهوه هـذه السياسة القرآنية العجيبة في الإصلاح؛ يسير 
Sutrisno Hadi,... ملامح الاتجاه الفقهي

ثم مع انقضاء عصر هؤلاء الأئمة دخل

الفقه مرحلة سرت في الناس-للأسف الشديد-

روح التقليد والتعصب لهؤلاء الأئمة، فقلما يجد

المـرء في آراء هـؤلاء المقلــين التسـامح واحسترام

رأى الغير، بلـ بلغ الأمـر ببعض هـؤلاء إلى أن

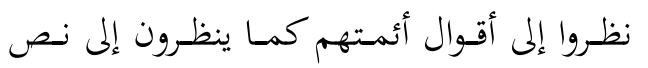

الشارع،

أمــا فن العصـر الحسديث وتحديــا منــذ

عهد الشيخ محمد عبده في أواخر القرن التاسع

عشـر وبدايـة القـرن العشـرين المـيلادى بـرزت

السمة الخاصة في منهج التفسير الفقهي تصحّح

مسيرته في العصور السابقة، وهذه السمات هى

دراسـة التفسـير الفقهـي دراســة بعيــدة عــن

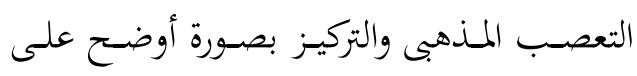

تحلية حكمة التشريع والإعجاز التشريعى للقرآن

والرد على الشبهات والتهم التى وُجهُت لأحكام

القرآن وتشريعاته في البحالات المختلفة- العبودية

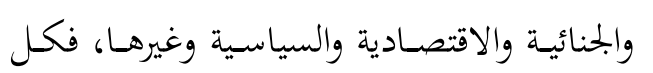

هذه الأشياء عرضها المفسرون المحدثون بأسلوب

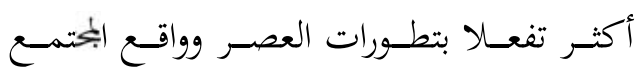

$$
\text { الإسلامى وتحدياته. (ج) }
$$

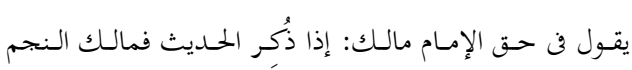

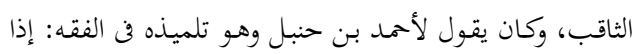

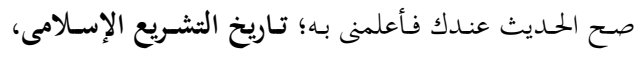

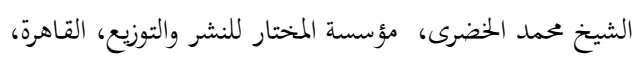

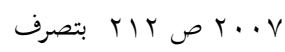

(1) اتجاهات التفسير الحديث فى مصر وسوريا ص

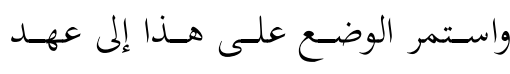

ظهـور أئمسة المـذاهب الفقهيـة وهــم الإمـام أبـو

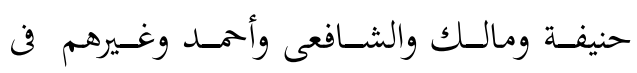
منتصف القرن الثاني الهجرى تقريبا، ومنذ ذلك الوقـت بـــأت الأمسور فن التشـعب وظهـرت الحـوادث الكثــيرة الستى لم تكــن موجـودة بــين المسـمين في السـابق، ولذلك بـدأكل إمـام فى النظر إلى هـذه الحسوادث المستجدة تحـت ضـوء

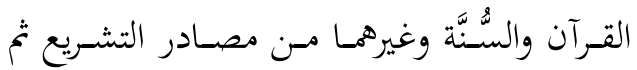

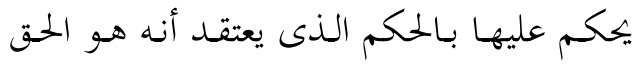
الذى يعاضـده الأدلة، ومنذ ذلك الحسين أصبح كلـل مـذهـب طريقتـهـ الخاصــة في اسـتنباط

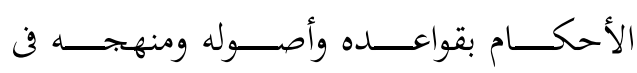
استخراجها.

وتتميز هذه الحقبة مـ التاريخ في أنه

مع كثرة اختلاف هؤلاء الأئمة في الأحكام إلا أنسه لم تظهـر مــنهم بــادرة التعصسب لــرأيهم

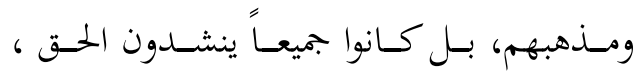
فلذلك نرى أنه ليس بعزيز على كل واحد منهم

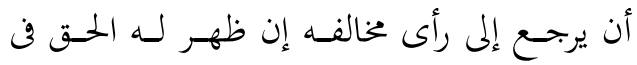

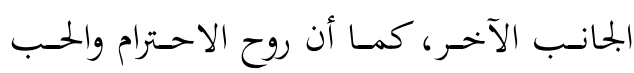
والتوقير يبقى سـائدا بيـنهم مـع اختلافـاتمم فن

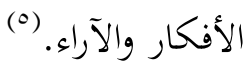

(o) تشير الكتب الكثيرة إلى النماذج الحية على مدى

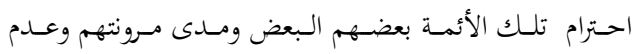

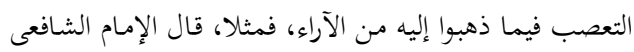
فن حق أبى حنيفة: الناس فن الفقه عيال على أبى حنيفة، وكان 
أمسا عن مؤلفاته فكثيرة ف بجالات دينية

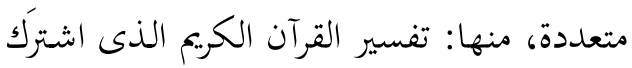

في إعداده الشيخ زين العارفين عباس (ولد عام

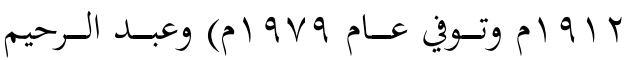

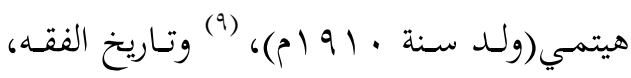

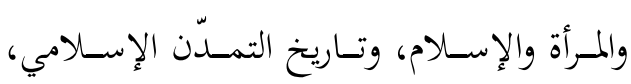

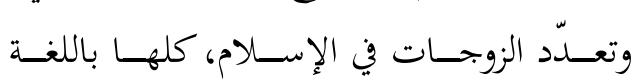

$$
\text { الإندونيسية. }
$$

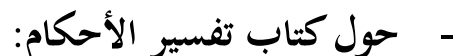

هذا التفسير أنخزه مؤلفه منذ نصف قرن الاحنام:

من الزمن تقريبا- أى في منتصف القرن العشرين

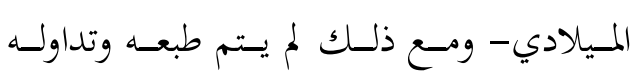

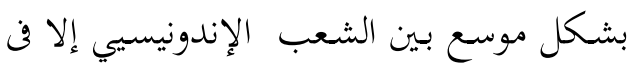

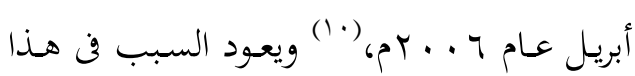

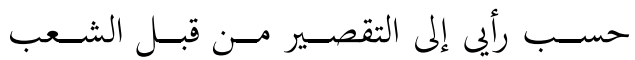

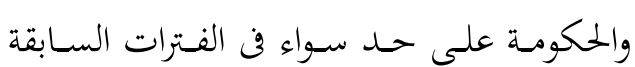
بتراث علمائهم وهو مـا يتمثل فن عـدم وجيود

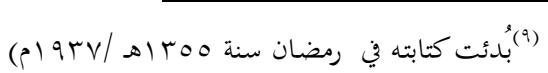

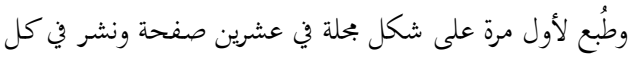

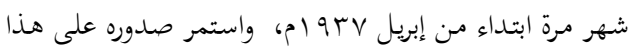

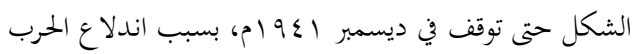

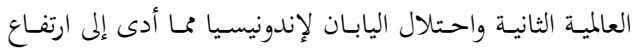

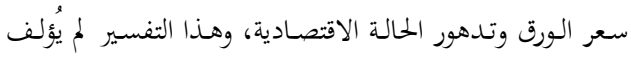

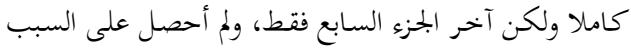

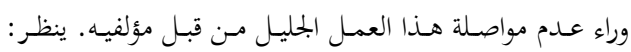

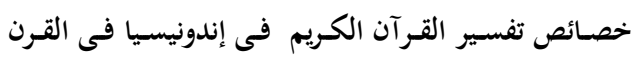
العشرين ص |0 -0 ب بتصرف يسير (·) وقد طبع الشيخ عبد الحليم حسن هذا التفسير في الماضى بعدد محدود للغاية ولم يتم تداوله بين الناس.
نبذة عن الشيخ عبد الحليم حسن وكتابه (تفسير الأحكام) - - ترجمة المؤلف

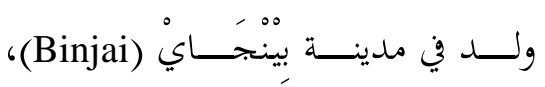

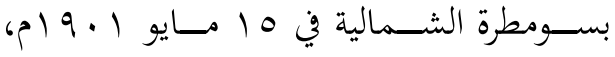
وكان من أسرة متدينة، ونشأ منذ طفولته على الصـلاح وحسـن الخلـق، كمـا تـربى على يــــ

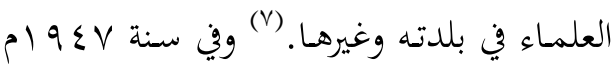

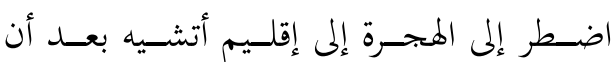
سـاءت الحالـة السياسـية فيها بسـبـب عسدوان الجحيش الهولندى، وأنشأ هنـاك مدرسـة ابتدائيـة

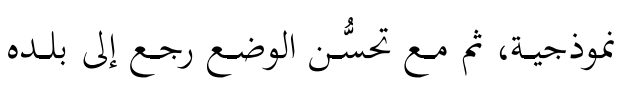
وواصـل مهنتسه في التــريس حستى تـوفى عـام (^). ค1 979 وقد تولى الشيخ عبد الحليم في حياته عـدة مناصـب، منهــا: مــدير المدرسـة العربيـة

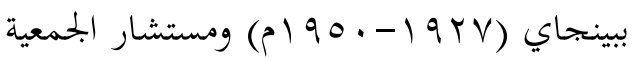

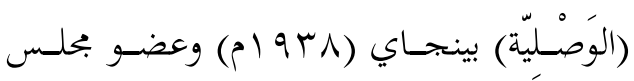
الترجـــيح بالجمعيـــة المحمديــــة في بينجـــــاي

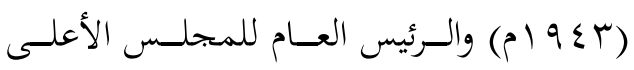
للشــؤون لإســالمية في بينجـــاي (ب ع 9 (م)، والمحاضـر بجامعـة سـومطرة الشـمالية الإسـلامية وغيرها.

$$
\begin{aligned}
& \text { (v) تساريخ العلمـاء البـارزين بسـومطرة الثــمالية، }
\end{aligned}
$$

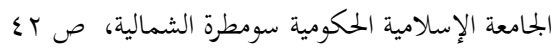

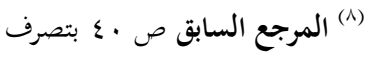


Sutrisno Hadi,... ملامح الاتجاه الفقهي

كمـا أن طبعـه يـتم بعـد وفاته إلا أنـه صسحيح

النسبة إليه، (r) (1)

و جـدير بالـذكر أن هـذا التفسير كتبـه

الشيخ عبد الحليم حسن بعد إبحاز تفسير آخر

اسمـه تفسير القرآن الكريم الذى كتبـه مـع اثنين

من رفاقه، هما الشيخ زين العارفين عباس وعبد

الرحيم الهيثمى ، و هـذا الأمر واضـح للبـاحثين

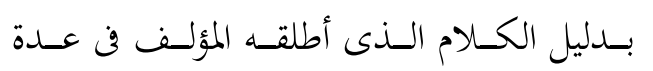

مواضع من هذا الكتاب حيث قال فيه: "انظر

تفسيرنا..." وبالطبع أن المقصود منه هـو كتابه

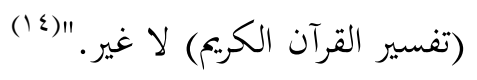

ويقـع هـذا الكتـاب الـذى يشــمل تفسـير

آيات الأحكام فن القرآن الكريم كاملا فن بجلد

واحسـ بحجـم كبسير حيـث يبلغ عسدد صـفحاته ع آ7 صــفحة، وطبــع فن مطبعسـة كينجانــا

في جاكرتـا، ويحتـوى الكتــاب (Kencana) على مقدمة و تفسير للآيات والخاتمة، والكتاب

(r) وفى هذا الشأن يقول الدكتور لحم الدين ناسوتيون

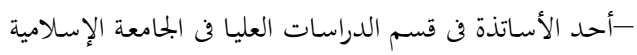

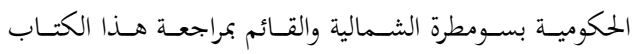

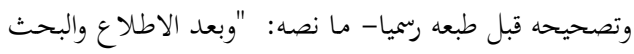

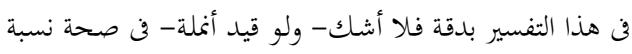

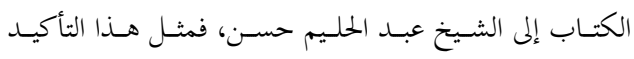

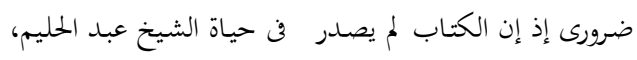

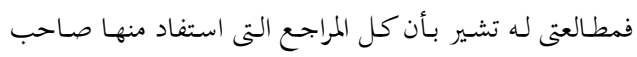

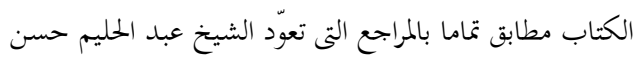

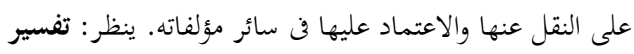

الأحكام ص 17 (المقدمة)

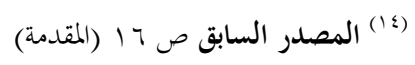

جهـة للقيـام بـإجراءات لازمـة لطبعه حتى جـاء

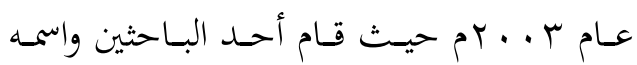

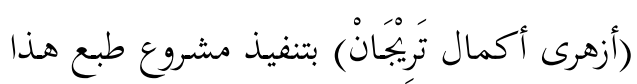
التفسير، ليستفيد منـه المسـلمون الإندونيسيون

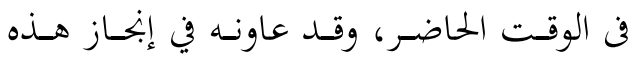

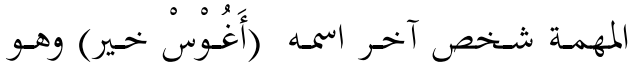
الذى بيده نسخة قديمة لهذا التفسير، (11)

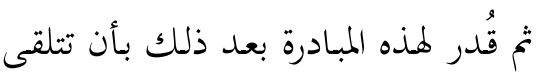

دعمـا كبـيرا مسن الجهـات المتعـددة -الحكوميـة والأهلية- فن سومطرة الشمالية، فهؤلاء أجمعوا على أن الكتـاب يحمل في طياته أفكارا متميزة فن شأن تفسير آيات الأحكام جديرة بأن يطالع عليها الناس في الوقت الحسالى، فضلا عن كون الكتاب تراثا ثقافيا فريدا من نوعه في هذا البحال لا ينبغى إهماله، (IT) وعلى الرغم من أن نسخة هذا الكتاب لم يؤخذ من يد الشيخ عبد الحليم حسن مباشرة

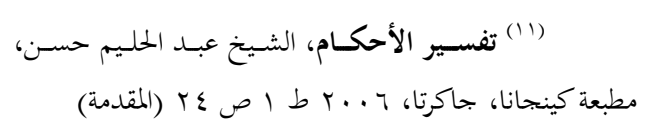

(Tafsir Ahkam, Abdul Halim Hasan, Published by: Kencana ، Jakarta, 2006, p 24)

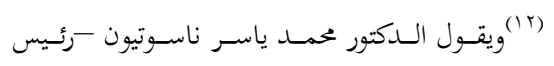

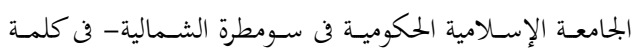

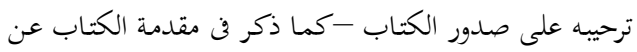
أربعـة أسباب على الأقل وراء حاجـة النـاس إلى مطالعـة هـــا

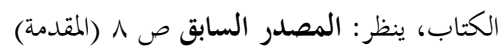


( ) تطـوير آفـاق المعرفـة للمجتمـع الإندونيسي

$$
\text { وتوسيعه }
$$

ץ) مســاعدة طلبـة العلـم في دروسـهم ودفعهـم على مواصلة الدراسـة-خاصـة الذذين قد تربعوا

مرتبة الثانوية والقسم العالى. (19)

وعن هاتين النقطتين أشار إليهما المؤلف لفان قائلا: "وألفنـا هـا الكتاب لزيادة وتطوير آفاق المعرفة خصوصـا لطلبة علوم الشـيعة الذين قد

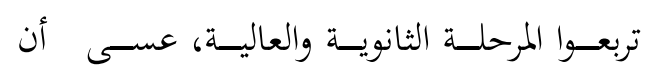

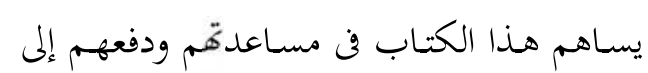

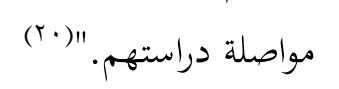

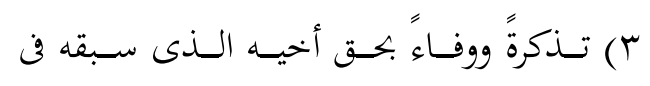

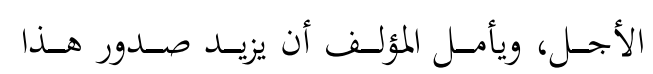

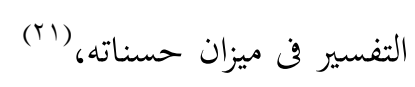

\section{طريقة عرضه:}

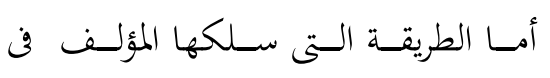

عرض كتابه فكانت تتسـم بالتيسير على القراء في فهـم محتـوى كتابـه واسـتخلاص الأحكـام والـدروس التى تضمنتها الآيـات المفسرة، فهذه الطريقة يمكن اختصارها كالآتى: 1- ذكر اسم السورة، و ذلك قبل الشروع فن تفسـير آيـات الأحكــام الموجــودة فيهـا،

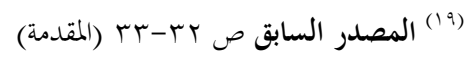

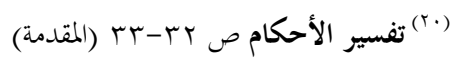
(T) وعن كلام الشيخ عبد الحليم حسن في هذا الأمر، ينظر: المصدر السابق ص بr (المقدمة)
يضـم تفسير . مب آيـة وهى التى عدّها الشيخ عبد الحليم حسن من ضسمن آيـات الأحكام في القرآن الكريم، (10) وهو في هذا العد يتبع رأى فئ الشيخ محمد صادق خندب في كتابه نيل المرام

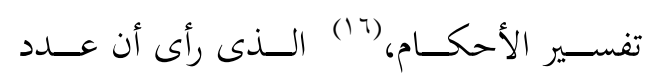
الآيات التى تعتبر من صنف آيات الأحكام لا تزيـد على مـائتى وبضعة آيـة، (IV) وللعلمـاء آراء متعـددة في هــا العـدد مـن بـين آيـات القـرآن الكريم كافـة وهـى التى تقـدر بـأكثر مسن سـتة آلاف آية، (1^) الدوافع والأهداف وراء كتابة هذا التفسير:

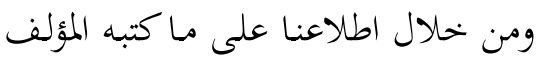
في مقدمـة هـذا التفسير بهـد بعض الإشـارة إلى

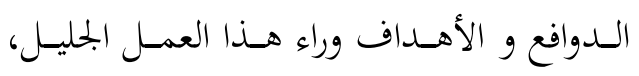

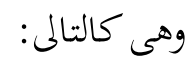
(10) أما السور التى ذكرت فيها هذه الآيات حسب :

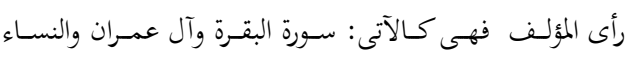

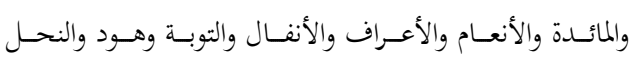

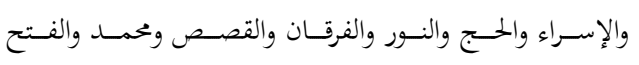

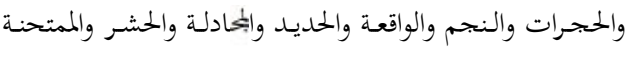

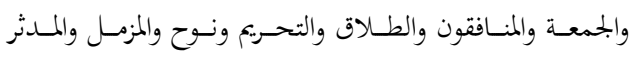

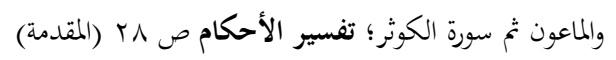

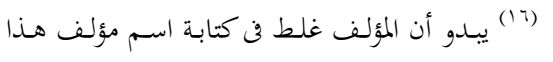

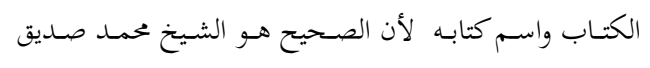

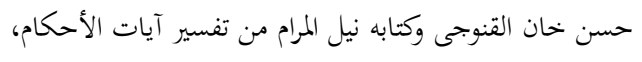

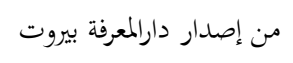

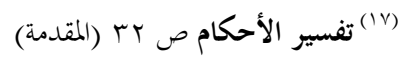

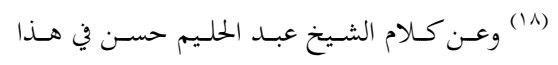

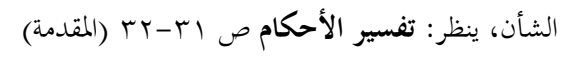


Sutrisno Hadi,... ملامح الاتجاه الفقهي

المؤلـف مـع صـاحبيه، بمعسنى أنسه اتسـم بكثـرة المصادر وتنوعها مما يدل على وسع آفاق معرفة مؤلفـه ودرايته بمصـادر التفسير عامـة و تفسير الأحكام خاصة، فهو ليرجع إلى جميع المصادر

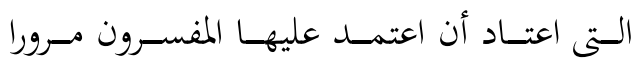
بــالقرآن الكـــيم والأحاديــث النبويسـة وأقــوال الصـحابة والتـابعين ثم أمهـات كتـب التفسـير بنوعيه-بالمأتور وبالرأى- ولاسيما كتب التفسير الفقهى.

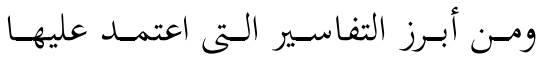

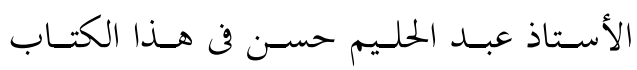
أحكام القرآن للجصاص و أحكام القرآن لابن العربى و أحكـام القـرآن للكيـا الهراسى والجـامع لأحكام القرآن للقرطبى، إضـافة إلى فتح القـدير

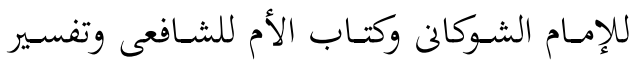
الكشاف للزخشرى.

ملامــح الاتجــاه الفقهي فـى هـذا الكتــاب ونماذج تفسيره:

الأول: الجمــع بــن الروايسة والـرأي، بمعـنى أن

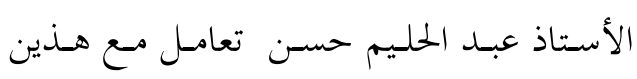

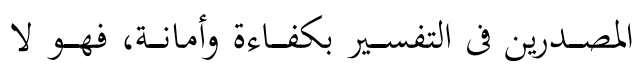
يسـتغنى أبــا بأحســهما دون الآخــر ولـو كــان جانـب الـرأى في هـذا الكتــاب أوضـح، ومــن خهالال مطـالعتى على تفسـيره أرى عرضسه كثيرا للآيـات والأحاديـث وأقوال الصـحابة والتـابعين
وإذاكـان للسـورة بعض الجوانسب التى أراد المؤلــف إفادتهـا إلى القــاء فإنـه يــكرها في هـامش الصفحة مباشرة، والمثال على هـذا الأمر ما ذكره في شأن سورة النساء، ץ- ذكر عنوان البحـث للآيـة التى أراد تفسير

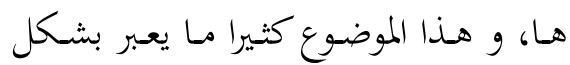
غـير مباشـر عـن استنباط المؤلف للحكـم الذى تضمنته تلك الآية. ب- ذكر رقم الآية التى أراد المؤلف تفسيرها. ع - ذكر نـص الآيـة باللغـة العربيـة، وقــ سـاقه المؤلف بخط واضح متبوع بالحركات بقصد تسـهيل القـراء - ولا سيما العوام مـنهم - تصني على قراءها.

ه- سرد ترجمة الآية باللغة الإندونيسية، وهـذه ترائ

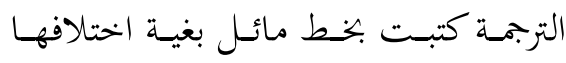
بشرح أو تفسير تلك الآية. ؟- ذكـــ تفسـير الآيسة باللغــة الإندونيسـية

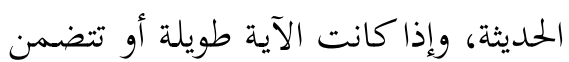

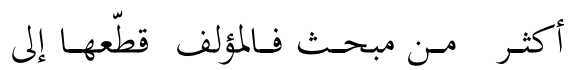

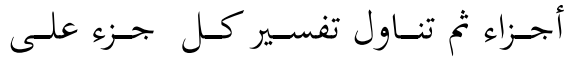
حدة، و في هذه الحالة لم يورد نص الآيـة

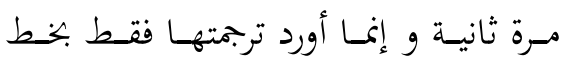
مائل ثم يبدأ بتفسيرها. المصادر التى اعتمد عليها فى هذا التفسير: في هـا الجحانب كـان شـأن هـا الكتـاب مثل كتـاب (تفسـير القـرآن الكريم) الـذى كتبـه 
الثانى: ذكر الآراء مع ترجيح رأى على الآخر،

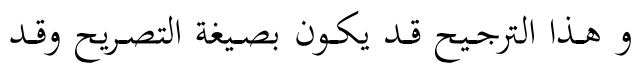

$$
\text { يكون بالتميح: }
$$

() ومثـال تـرجيح المؤلـف الـرأى على الآخــر

$$
\text { بصيغة صريكة: }
$$

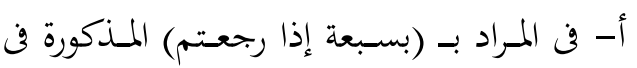

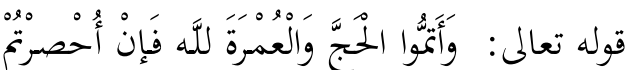

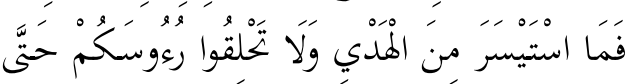

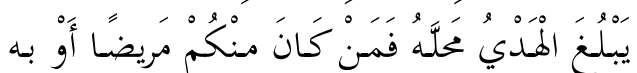

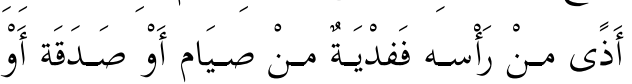

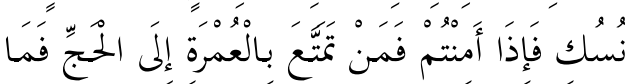

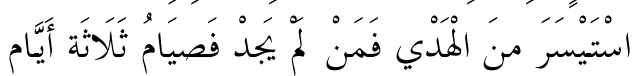

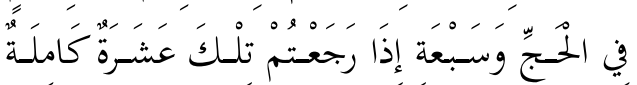

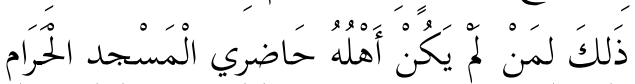

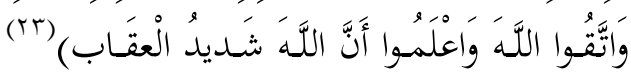
حيث قال الأستاذ عبد الحليم حسن: "أى إذا

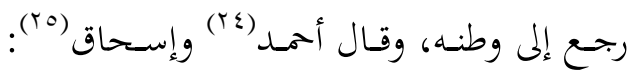
يجـوز لـه أن يـؤدي هـــه الأيسام فن طريقـه إلى بلده، ومثل هذا قال الشـافعي (ٓr) وقتادة وربيع

$$
\begin{aligned}
& \text { 19 (ST) }
\end{aligned}
$$

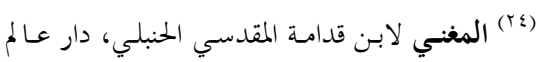

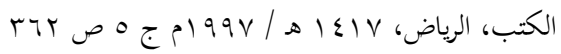

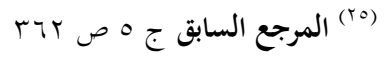

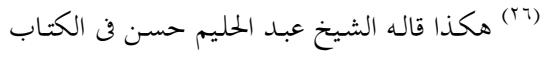

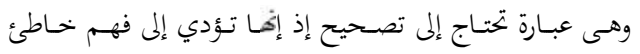

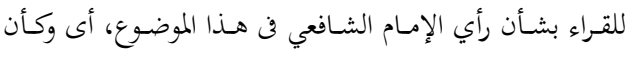

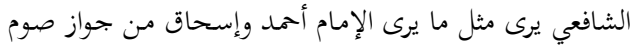

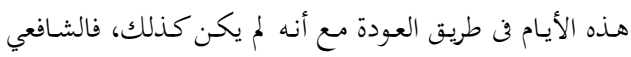

وكذلك أسباب النزول وكلها فن ثنايا ذكره لآراء المفسرين والفقهاء من المذاهب المختلفة. و فن شأن أسباب النزول بشكل خـاص تهن يبـدو أن المؤلف ملتزم بالتطرق إليه اعتقـادا منهـ

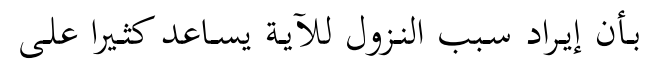
كشـف معـنى الآيـة وبالتـالى استنباط الأحكـام الموجودة فيها، وإذا كان للآية الواحدة أكثر من

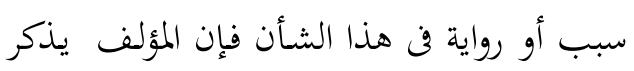

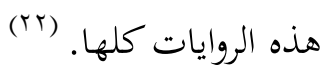

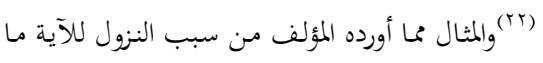

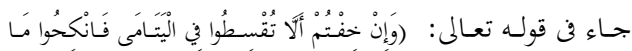

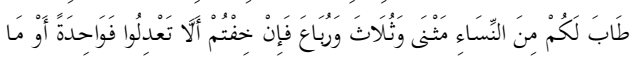

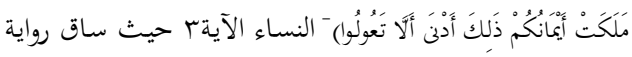

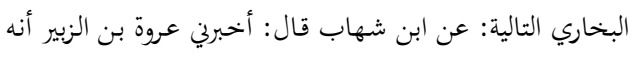

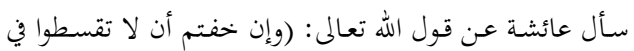

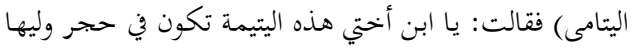

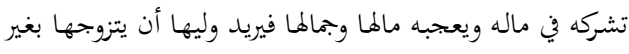

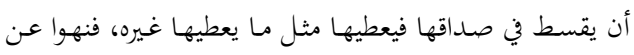

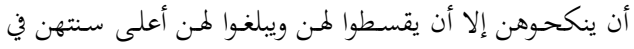

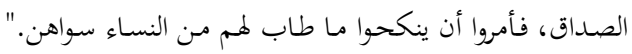

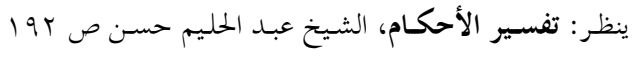
وبشأن الرواية ينظر: صحيح البخارى، كتاب التفسير (تفسير

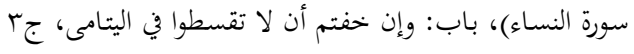

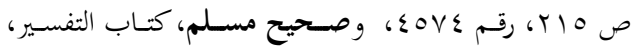

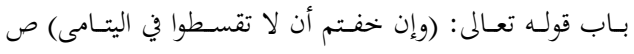

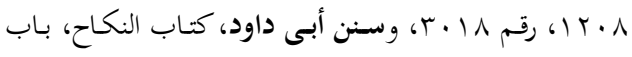

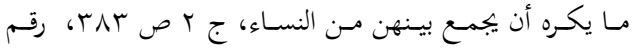
$r \cdot T \Lambda$ 


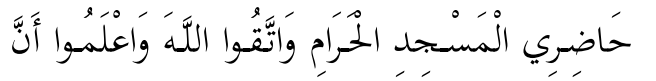

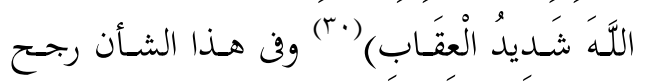

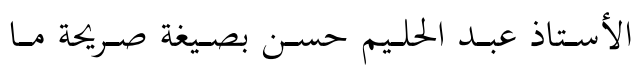
ذهـب إليـه الإمـام الشـوكانى، حيـث قـال: "أمـا عـن مكـان تسـليم هـذه الفديـة فعنـد عطلاء أنهـ إذاكـان دما فيسـلم بمكة ولكن إذاكـان إطعام المسـاكين أو الصسوم فيجـوز فن أى مكان شـاء،

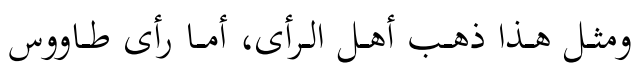
والشافعى فذبح الشاة وإطعام الطعام لا يكونان

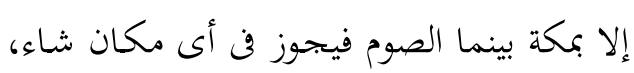

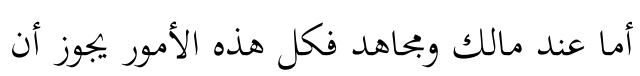
يؤديسه الشـخص في أى مكـان شـاء، (آم) وقـال

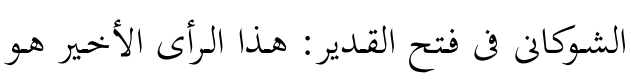

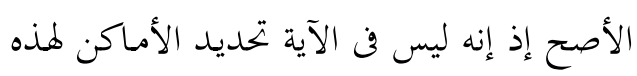

وبحاهـــ وعكرمسـة والحســن (TV وآخــرون، أمــا

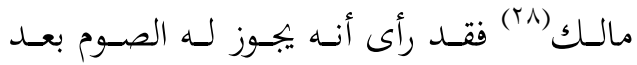
عودته مـن منى وقبل السفر إلى بلده، وإذا قارنا بـين هـذين الرأيين فـالرأى الأول هـو الأقوى لما لـا روى في حديث صحيح عن ابن عمر أن رسول

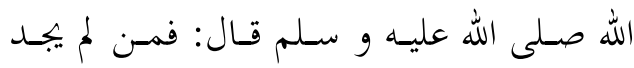
فصيام ثلاثة أيام في الحج وسبعة إذا رجع إلى

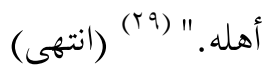
ب- في شـأن المكان الذى يؤدى فيـه الحجـاج

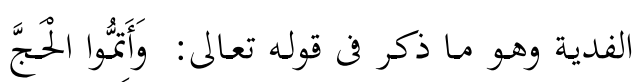

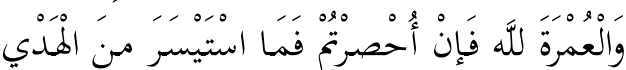

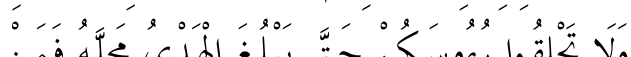
ولا تحلقوا رعوسكَم حتَّى يبلغ الهدي محلَّه فمسن

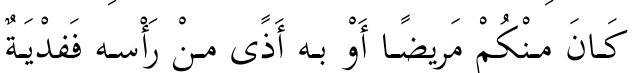

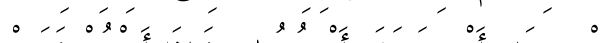

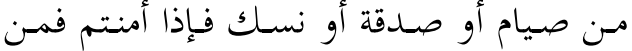

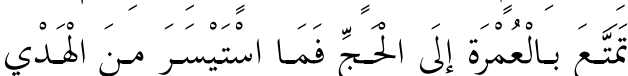

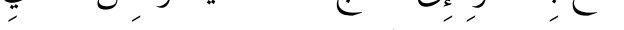

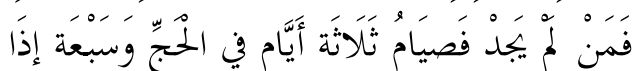

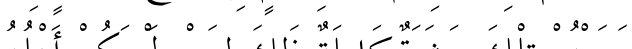

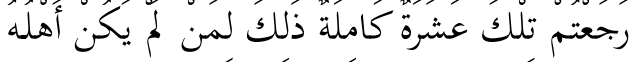

ذهب إلى أدائها إذا رجع الحاج إلى وطنه وأهله ولا يجوز صومها

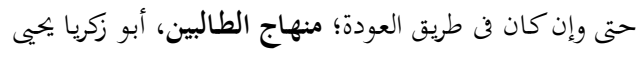

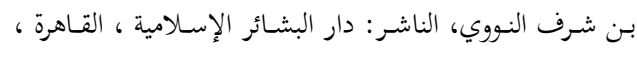
( ب...o كام

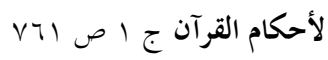

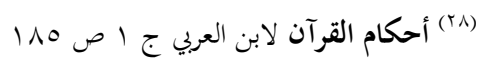

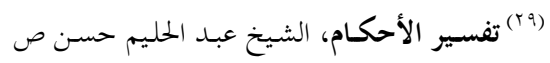

$$
\begin{aligned}
& \text { ه7 وروى الحديث بمعناه وهو طرف من رواية البخارى الطويلة }
\end{aligned}
$$

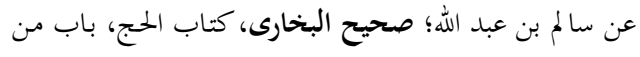

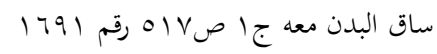


ولنا

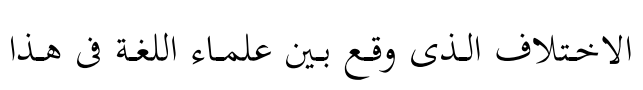

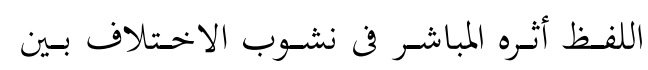

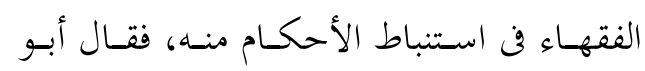

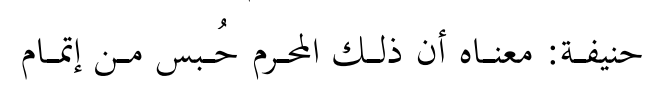
إحرامه إمـا بسبب العدو أو بسبب المرض، (ro)

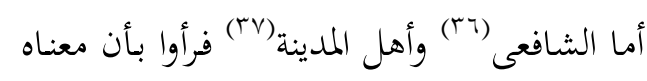

(َ) يبدو أن المؤلف استنبط جملة هذه الأقوال لعلماء

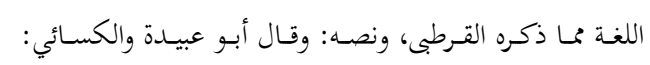

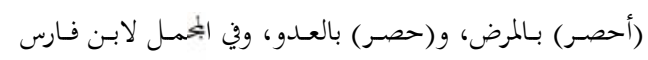
على العكس، فحصر بالمرض، وأحصر بالعدو، وقالت طائفة:

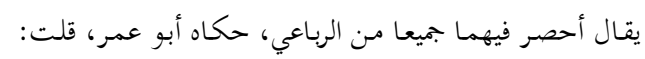

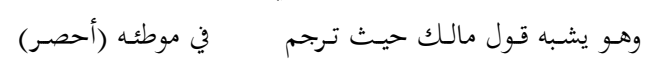

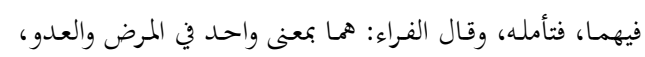

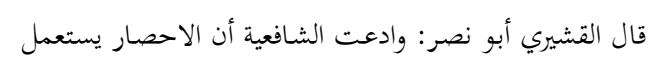

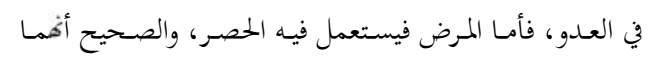

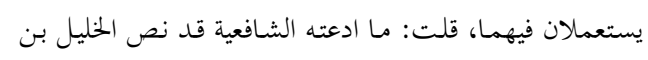

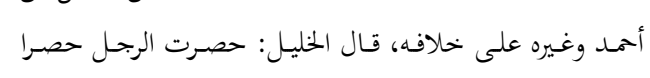

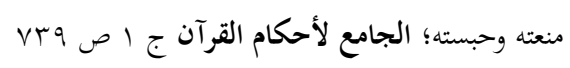

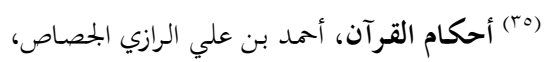

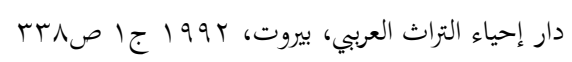

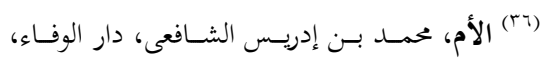

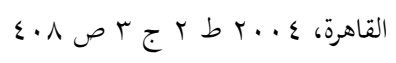

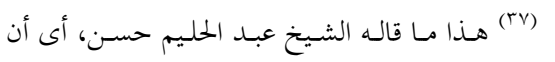

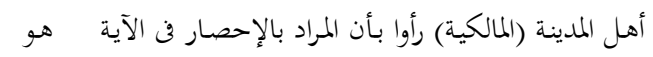

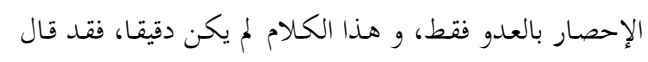

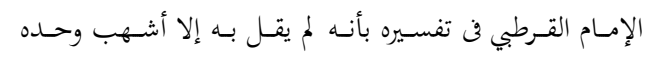

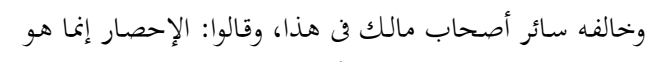

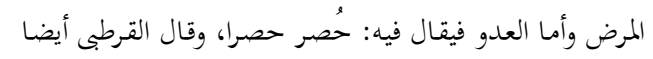

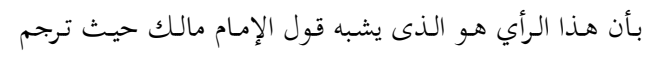

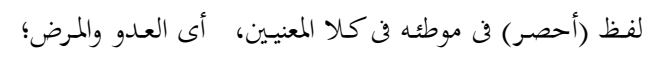

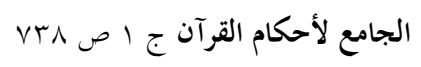

الأشسياء."(rr(آ) (انتهى كـلام الشـيخ عبـد الحليم حسن) ب) ومثــال تـرجيح المؤلـف الـرأى بصـيغة غـير صسريكة هـو : فن شـأن مــلول لفـظ (أحصـرتم)

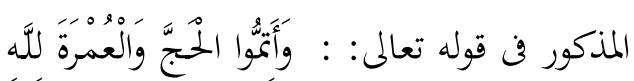

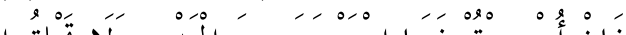

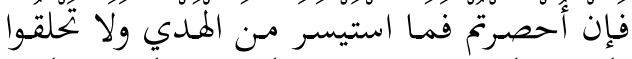

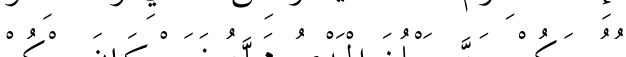

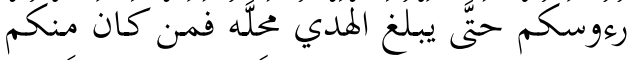

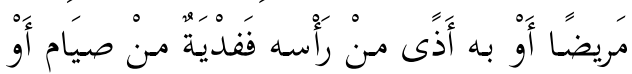

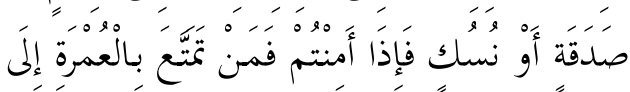

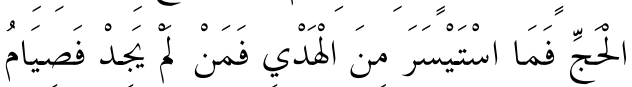

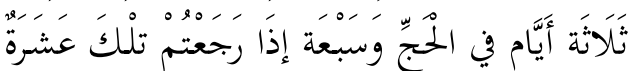

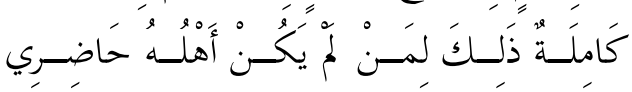

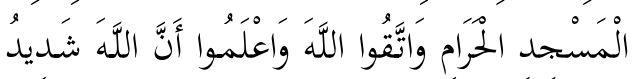

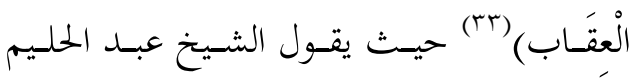
حسن عند تفسيرها: "فلفظ (أحصرتح) معناه في اللغــة حبسـتم أو أسـرتم، قـال الكســائى وأبـو عبيـدة والخليـل أنسه: الحـبس بسـبـب المـرض، أمـا (rr) تفسير الأحكام للشيخ عبد الحليم حسـن ص

عا ونص كلام الشوكاني: "واختلفوا في مكان هذه الفدية فقال عطاء ما كان من دم فبمكة وما كان من طعام أو صيام فحيث شاء وبـه قال أصحاب الرأي وقال طاوس والشـافعي الإطعام

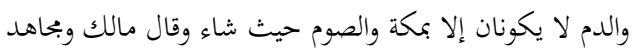
حيـث شـاء في الجميـع وهـو الحـق لعـدم الــليل على تعيسين المكان." ؛ فتح القدير، محمد بن علي بن محمد الشوكاني، دار الفكر ، بيروت ج ال ص 197

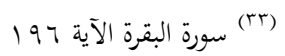


Sutrisno Hadi,... ملامح الاتجاه الفقهي

وقـال الأسـتاذ عبــــ الحلـيم حســن فيـه:

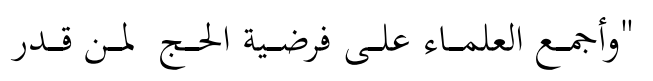

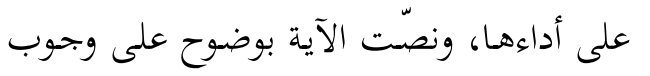
إتمام الحـج والعمـرة أى وجـوب آدائهما، ل لأن

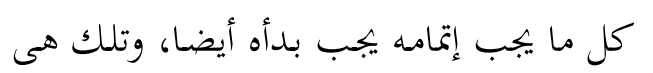
حجـة العلمـاء الـذين يـرون فرضـية أداء العمـرة،

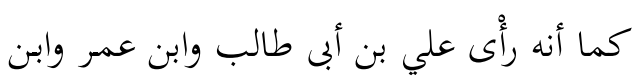

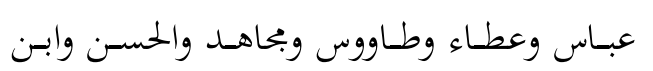

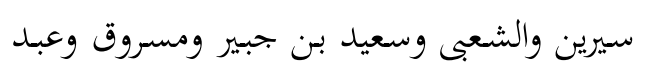

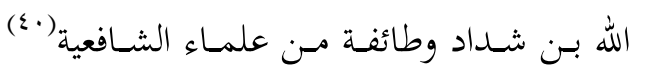

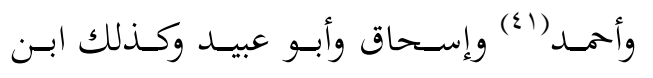
الجهـــم مــن علمــاء المالكيــة، ولكــن الإمــام

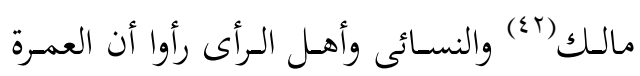
تطوع، ومسن الصحابة الذين يقولون أيضـا بهذا

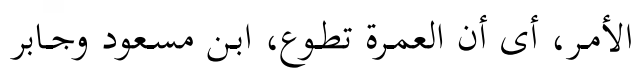

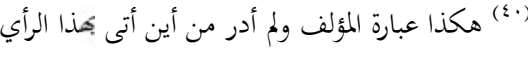

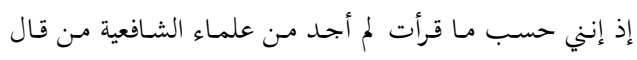

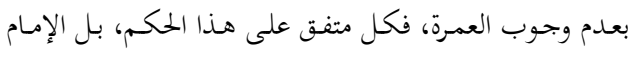

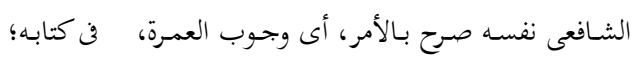

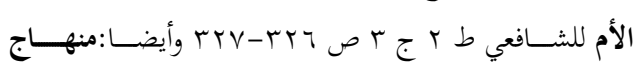

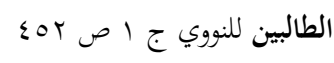

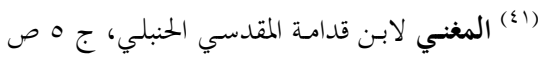

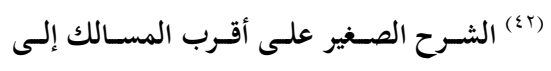

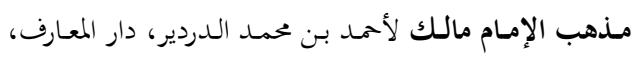

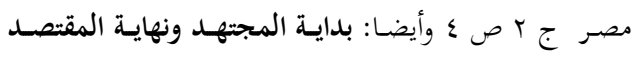

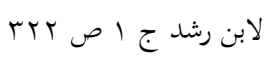

ir
الحسبس بسـبب العـدو فقطه، وقـال الجمهـور: والذى حبس من مواصلة أو إتمام إحرامه بسبب العـدو فليحلـل مـن الإحــرام ويـدفع الفديـة فن المكان الذى حبس، كما فعله الرسول صلى الله عليـه و سـلم وأصسحابه في الحديبيـة، وهــم قـــ مــنهـم قــريش مــن دخهـول مكـــة لإتمــام إحرامهم. "( (")

ففى هـــه المسـألة نـىى أن الأستاذ عبــ الحليم حسن لا يرجح بشكل صريح هنـا رأى

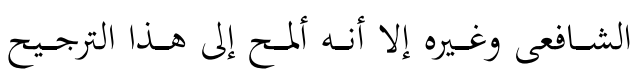

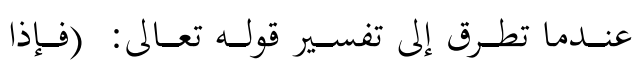

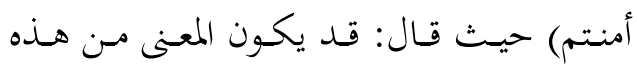
الآية (الأمان من المرض أو العدو) ولكن الذين رأوا بـأن معنـاه (الأمـان مـن العـدو) أكثر دليلا وشرحا من الذين رأوا بأن المراد هو (الأمان من الدان

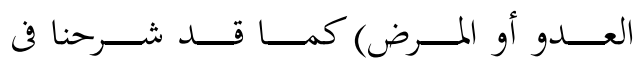

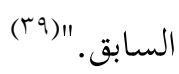

الثالث: ذكر الآراء المتعددة التى وردت في قضية واحدة مع دليل كل ولكمن دون محاولة للجمع ألح أو الترجيح، ومثال ذلك كلآتى:

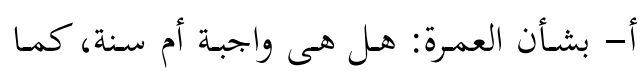
فن قوله تعالى في سورة البقرة الآية 197

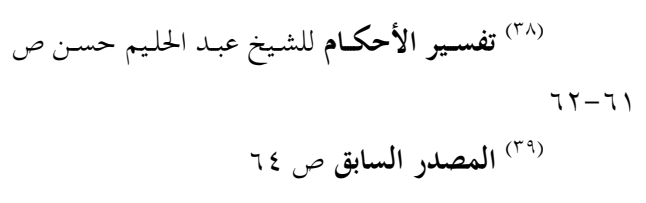




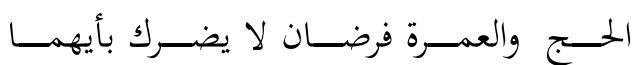

$$
\text { بدأت." (๕) }
$$

أما دليل الفريق الثانى هو:

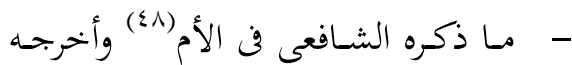
عبد الرزاق وابن أبى شيبة(9 §) وعبد الله

بن حميد عن الصالح الحنفى أن رسول

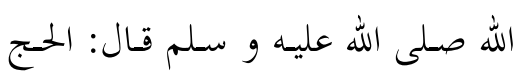

جهاد والعمرة تطوع."

- مـا روى عن عبـد الله بـن حامـد - ـوقـال

الترمذى: صحيح- من حديث جابر قال:

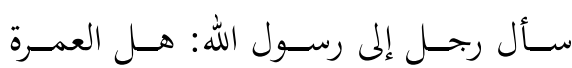

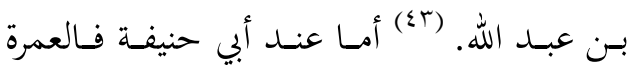
واجبة وليست بفرض. (ع §) وأدلة من ذهب إلى فرضية العمرة هى: - حديث رسول الله صلى الله عليه و سلم إلى أصحابه: "من كان معه هدى فليهل بالحج مع

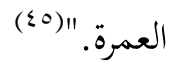
- حسديث رسـول الله صـلى الله عليـه و سـلم: دخلت العمرة في الحج إلى يوم القيامة."(־؟) - أخرج الدارالقطنى والحاكم من حديث زيد بن ثابت أن رسول الله صلى الله عليه و سلم قال:
نق نقل المؤلف هذا الحديث بمعناه، ونصه: عن زيد

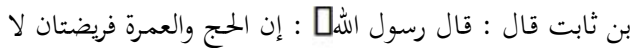
يضرك بأيهما بدأت؛ المستـدرك على الصسحيحين، الحساكم،

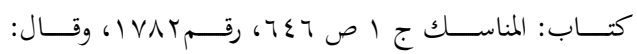

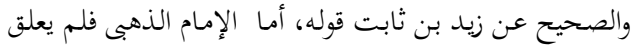

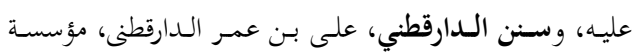

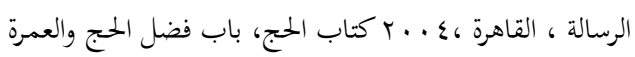

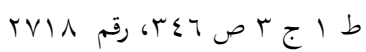

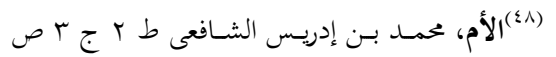

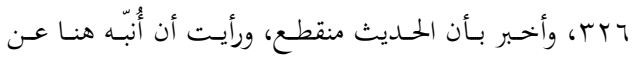

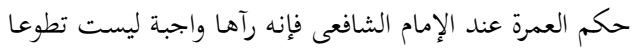
و هـذا التنبيه مهـم لأن لا يظـن النـاس أن العمـرة عنـــ الإمـام

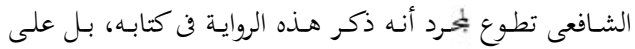

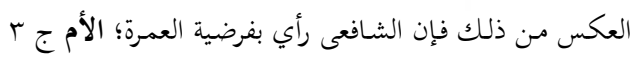
TrV-rTt ص

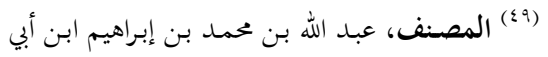

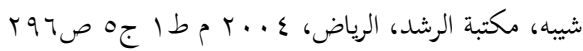

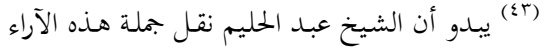

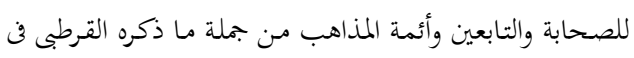

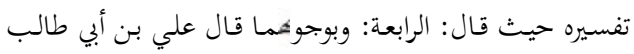

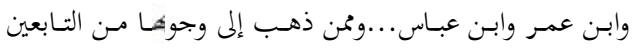
عطاء وطاوس وبحاهد والحسن وابن سيرين والشعبي وسعيد بن

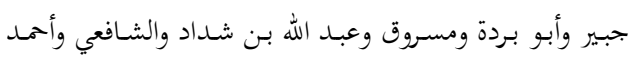

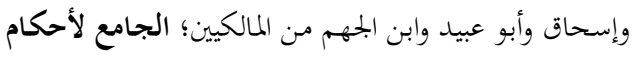

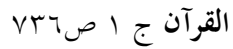

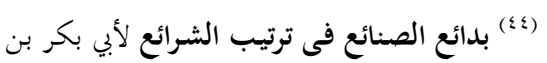

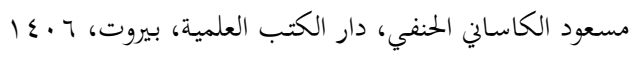

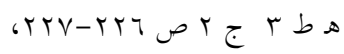

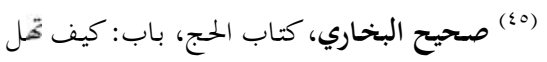

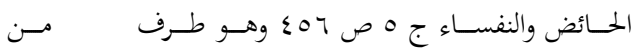
حديث طويل عن عائشة رضى الله عنها.

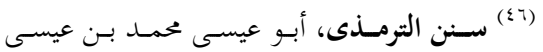

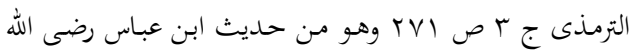

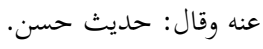


Sutrisno Hadi,... ملامح الاتجاه الفقهي

والشافعي(\&) بأنه لا يقام على سارقه الحد، أما ابن وهب فقد روى عن مالك وماد بن أبي

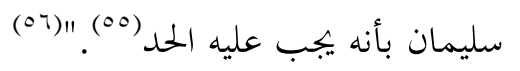
الرابع : استنباط بعض الأحكام التى تؤخذ مـ

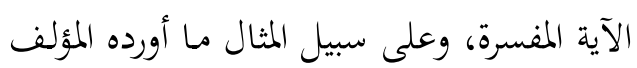

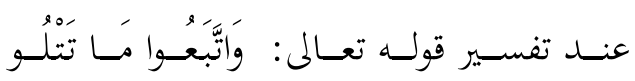

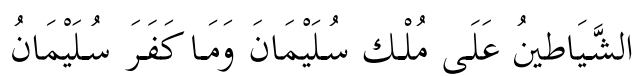

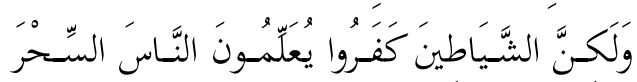

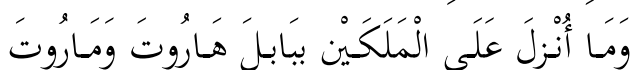

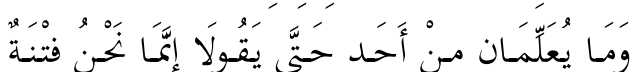

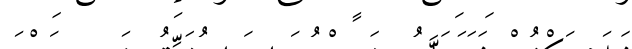

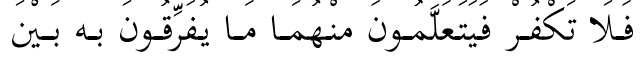

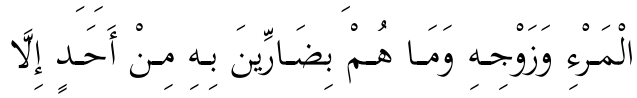

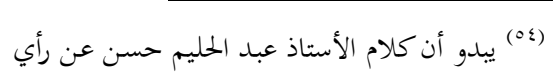

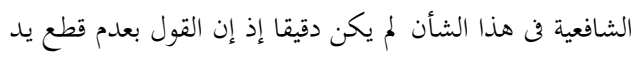

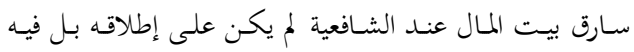

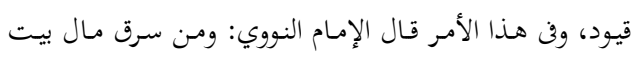

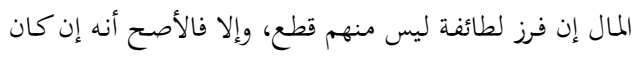

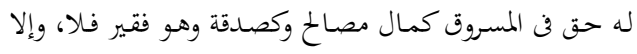

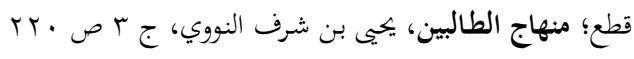

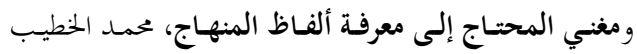

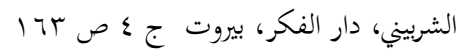

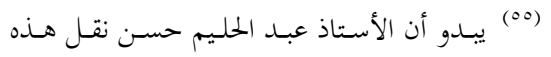

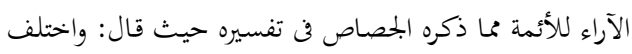

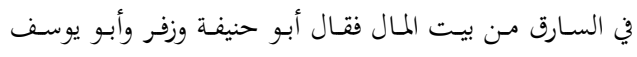

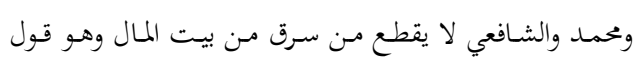

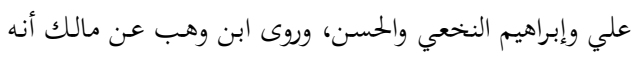

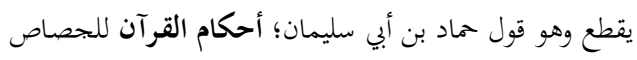
VV (4) تفسير الأحكام للشيخ عبد الحليم حسن ص

rev-rvi
واجبب؟" فقال: لا، وأن تعتمر خير لك."

ثم إفم - أى هذا الفريق الثانى - أولّوا بعد ذلك معنى الآية السابقة وقالوا بأن فرضية أداء العمرة لفرد من الأفراد سببه لأن ذلك الفرد قد فرضها على نفسه، ففى قاعدتم أنه يجب إتمام العمل

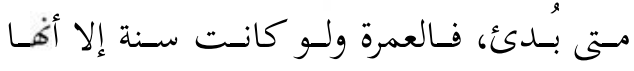

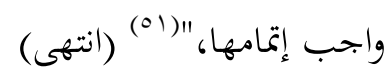
ب- في البيان عن حكم سرقة مال الدولة، وذلك عند تفسير قوله: وَالسَّارقُ وَالسَّارقَةُ

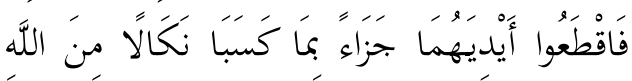

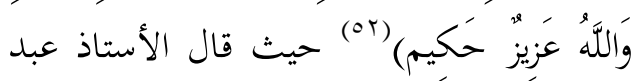
الحليم حسن: "وذهب أبوحنيفة وأصحابه(ror)

(0) سـن الترمذي ، كتاب الحسج، بـاب مـا جـاء في

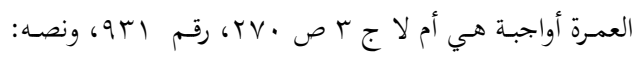

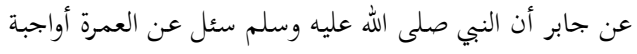

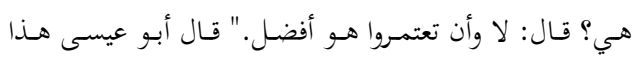

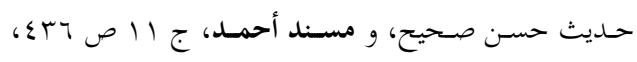

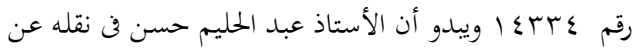

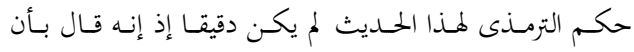
الحديث (صحيح) مع أن الترمذى قال: حسن صحيح.

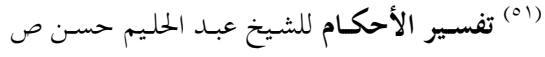

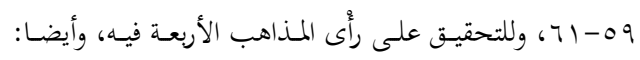

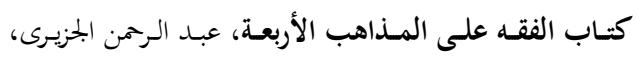

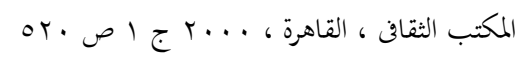

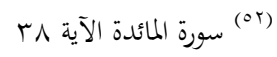

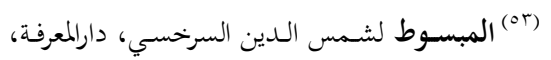

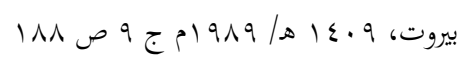


ثانيا: بأن السحر يحدث أثرا في قلب الإنسان

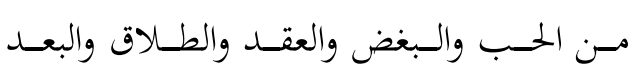

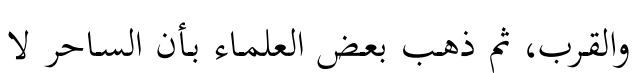
يقـدر على فعل أكثر مما قـد بين الله سبحانه وتعالى في هذه الآية وهو التفريق بين الرجل

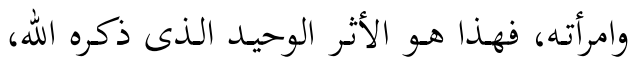
فلو كان السحر يقدر على إحداث آثار أخرى

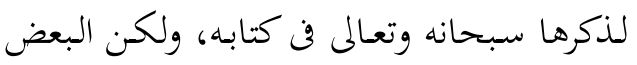

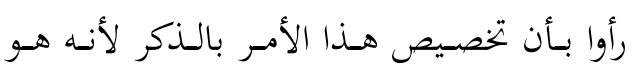

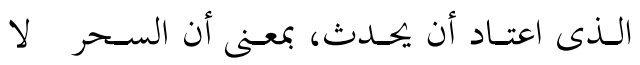

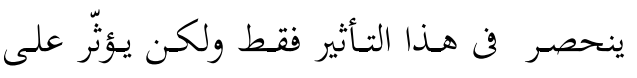

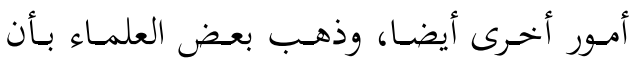
السحر ليس له أثر أبدا لأن الله سبحانه وتعالى,

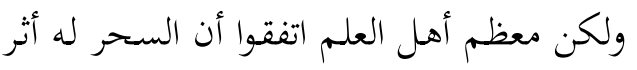

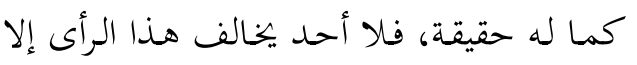

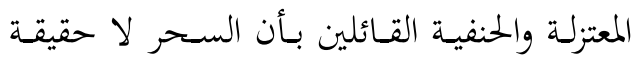
S

وقــال الإمـام أبـو السـعود في تفسـيره:

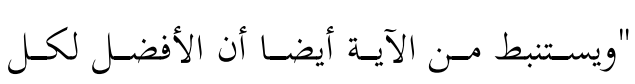

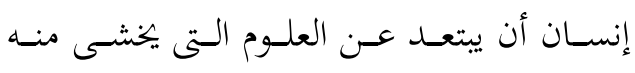

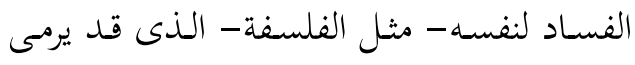

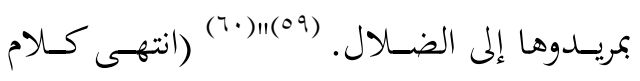
الأستاذ عبد الحليم حسن)

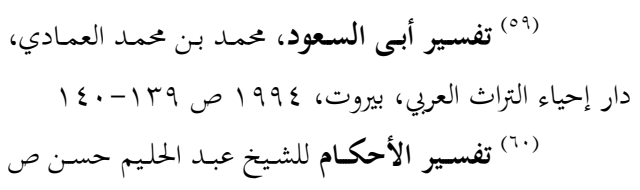

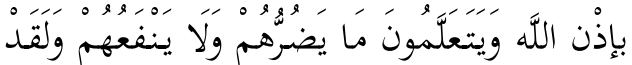

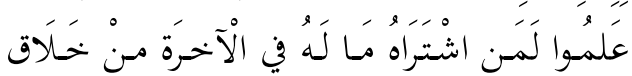

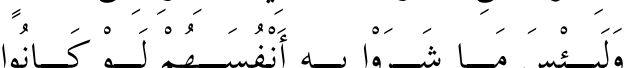

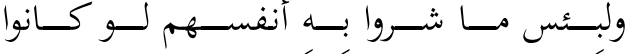

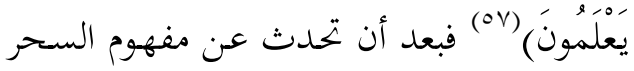
وآراء العلمـاء فيـه وهـل له حقيقـة أم لا، سـاق لعاق

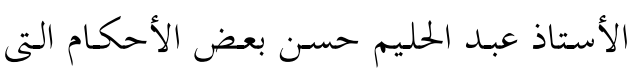

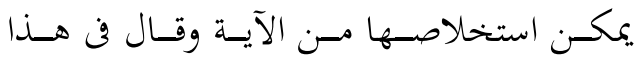

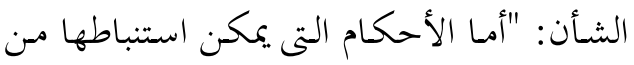

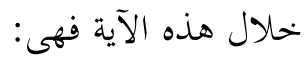
أولا: قال الإمام الشوكان فن تفسيره: كل الذى لهى تعلّم السـحر صـار كـافرا بـذلك الفعـل لأنسه

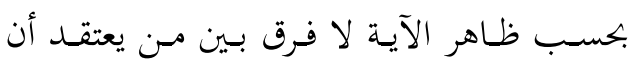

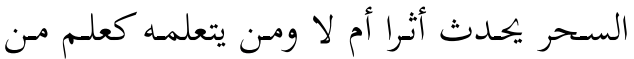

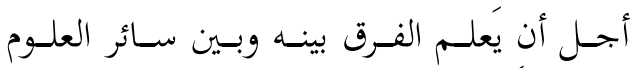
وكذلك من يتعلمه كأداة للدفاع عن نفسه من

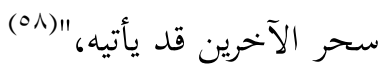

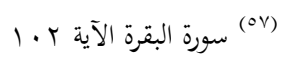

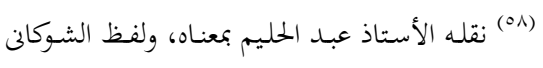

$$
\begin{aligned}
& \text { فيه: وفي قولما ( فلا تكفر ) أبلغ إنذار وأعظم تحذير أي أي أن أنسان }
\end{aligned}
$$

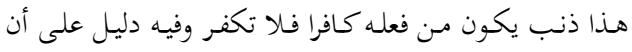

$$
\begin{aligned}
& \text { تعلم السحر كفر وظاهره عدم الفرق بين المعتقد وغير المعتقد }
\end{aligned}
$$

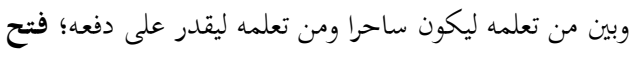

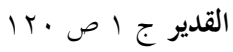

$$
\begin{aligned}
& \text { ولكن بعض العلماء أجازوا تعلم السحر لأحد أمرين: }
\end{aligned}
$$

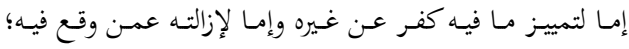

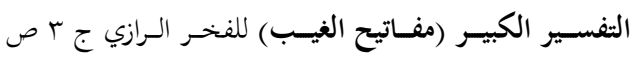

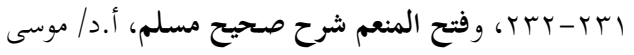

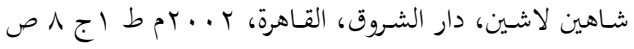


ملامح الاتجاه الفقهي Sutrisno Hadi,..

1- أن المؤلف في كثير مـن الأحيـان يتصـرف كمجرد ناقل لآراء العلماء والفقهاء، فهو

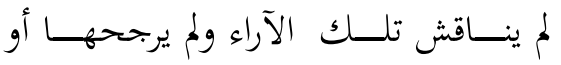

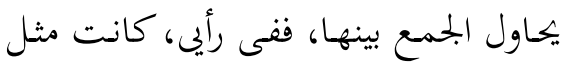

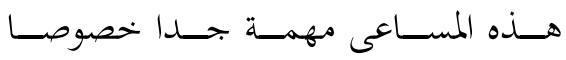

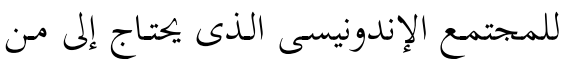

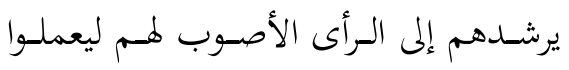

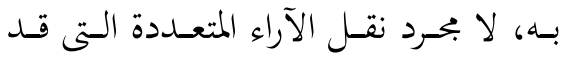
تخالف بعضها ببعض، r- وقريب من الملاحظة السابقة فإبن أرى أن

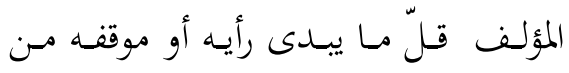

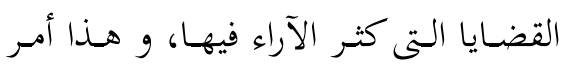

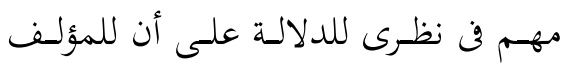
شخصية واضحة في كتابه ولا يكون بحرد

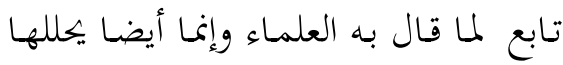
بل حتى يعترض عليها إذا رأى أن الصواب في غيرها.

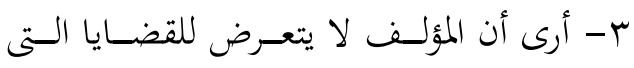

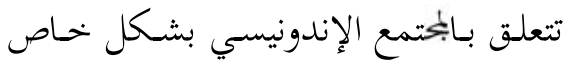
مع أنه مقبل على عمل له الارتباط الوثيق لإنديق

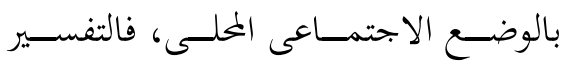

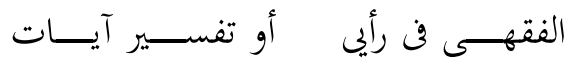

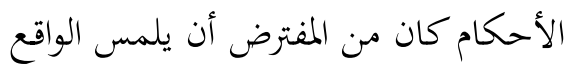

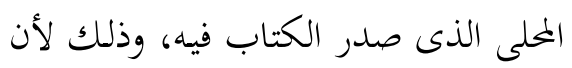

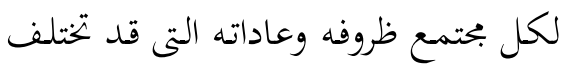

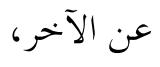

خاتمــة: القيمــة العلميـة للكتــاب وبعـض الملاحظات عليه أرى أن العمل الذى قام به الأستاذ عبد

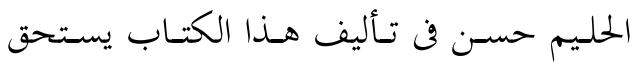
التقدير بجدارة إذ إنه أول كتاب في تفسير آيات

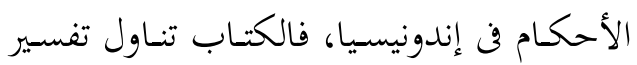
آيـات الأحكـام بعمـق وانفتـاح فن حسين كـان التعصب المـذهبى هـو سيد الموقف في البلاد،

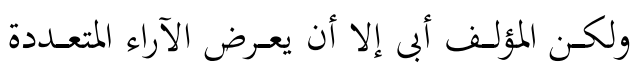
للعلماء في كل القضايا بلا تعصب لرأى مذهب التراء

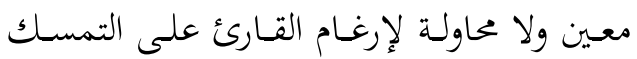
برأى ذلك المذذهب، ولكـن يجبـ التنبيه بـأن

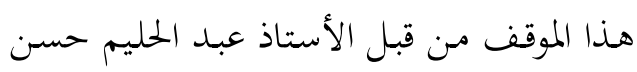
لا يعنى أنه ترك قارئيه بلا توجيه ولا إرشاد وإنما

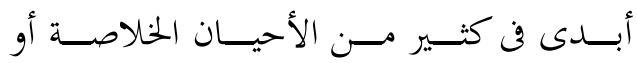

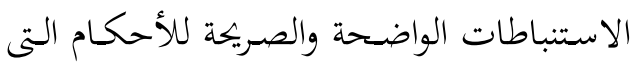
تضمنتها الآية.

ثم مـع عمسق هـذا البحـث وسـعته فبإن طريقة عرض هذا الكتاب تبقى بسيطة وميسرة

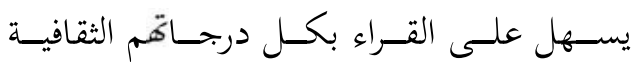
(71) الاستفادة بما فيه ولكـن بصفته البمهـود البشرى الذذى لا لا

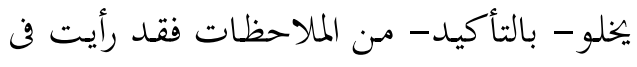
الكتاب بعض الأمور التى يمكن اعتبارها مآخذ على المؤلف، منها: 
ع - أن المؤلف في كثير مـن الأحيـان لا يعـزو أحمد بن علي الرازي الجصاص، أحكام القرآن،

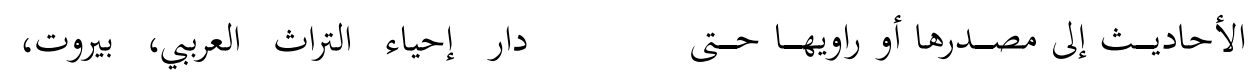

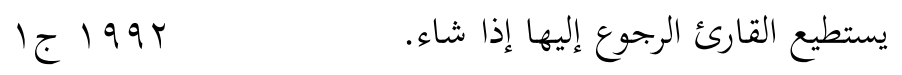

ه- أن المؤلـف فن بعض القضـايا لا ينقـل آراء أحمد بن علي بن حجر أبو الفضل العسقلاين

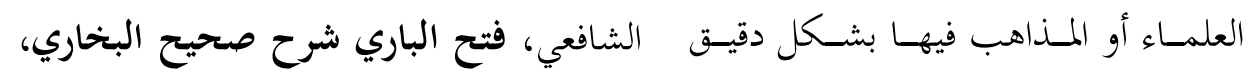

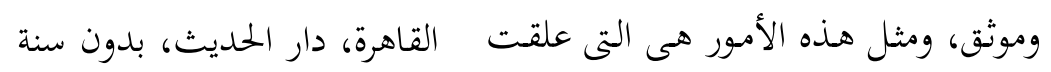

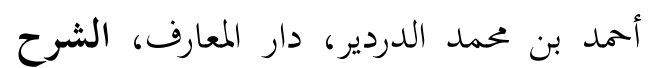

الصغير على أقرب المسالك إلى الى مالى

عليها فن هامش الرسالة.

مذهب الإمام مالك قوله تعالى: مصر آتر

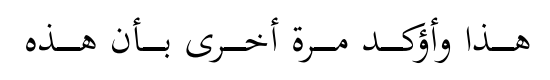

الملاحظات أو المآخذذ لا تنقص من فضل هذا

$$
\text { الكتاب وقدر مؤلفه ولكنها مما ينبغي ذكره في }
$$

أحمد بن محمد بن حنبل، المسند، جبا

(القاهرة: دار الحديث، 1990 (1)

طا، تحقيق: أحمد شاكر (القسم

\section{قائمة المراجع}

الأول) وحمة أحمد الزين (القسم الثانى)

ابن قدامة المقدسي الحنبلي، المغني، دار عالم

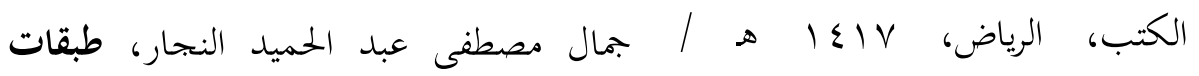

واتجاهات تفسيرية، (القاهرة: مكتبة

$$
\text { - ج pl99V }
$$

$$
\text { الحسين الإسلامية، بدون سنة) }
$$

أبو بكر بن مسعود الكاساني الحنفي، بدائع

عبد الحليم حسن، تفسير الأحكام، مطبعة

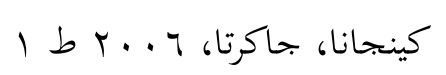

الصنائع فى ترتيب الشرائع، دار

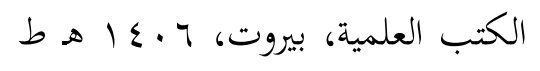

Abdul Halim Hasan, Tafsir Ahkam,

(Kencana: Jakarta, 2006)

عبد الرحمن الجزيرى، كتاب الفقه على :لى المذاهب الأربعة، المكتب الثقافى ،

$$
r \text { r }
$$

أبو زكريا يهيى بن شرف النووي، منهاج

الطالبين، الناشر: دار

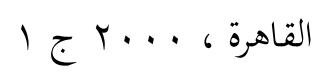

عبد الله بن محمد بن إبراهيم ابن أبي شيبه،

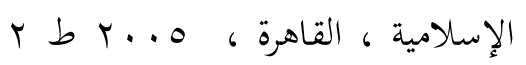

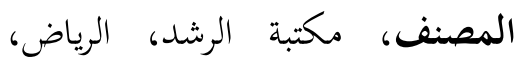

$$
\text { ج }
$$




$$
\begin{aligned}
& \text { على بن عمر الدارقطنى، سنن الدارقطني، محد بن أحمد الأنصارى القرطبى، الجامع }
\end{aligned}
$$

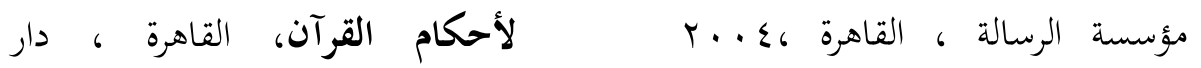

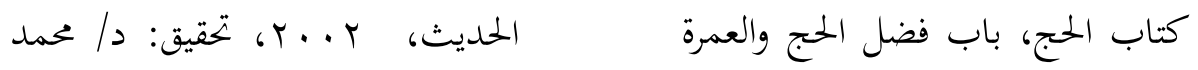

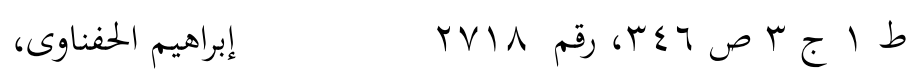

$$
\begin{aligned}
& \text { فخر الدين بن ضياء الدين عمر الرازى، تفسير محمد بن إدريس الشافعى، الأم، دار الوفاء، }
\end{aligned}
$$

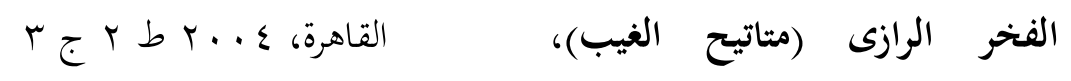

$$
\begin{aligned}
& \text { بيروت، دار الفكر للطباعة والنشر، محد بن إسماعيل بن إبراهيم البخارى، الجامع }
\end{aligned}
$$

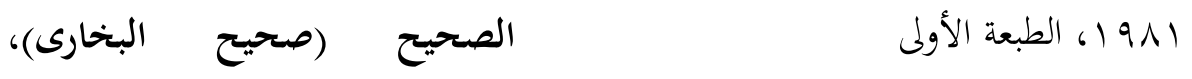

$$
\begin{aligned}
& \text { الحديث فى مصر وسوريا، (رسالة الطبعة الأولى }
\end{aligned}
$$

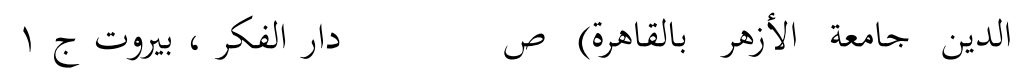

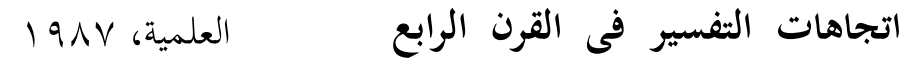

عشر، الرياض، مكتبة الرشد، محمد بن محمد العمادي، تفسير أبى السعود،

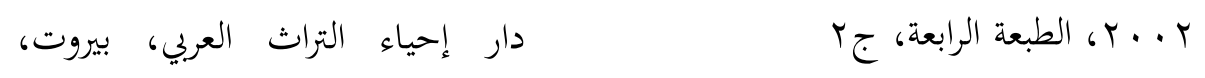

لمنة المعدين، تاريخ العلماء البارزين بسومطرة

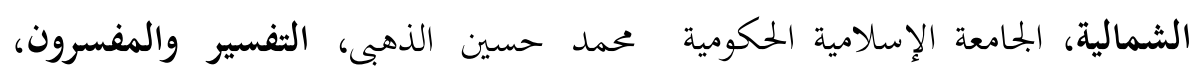

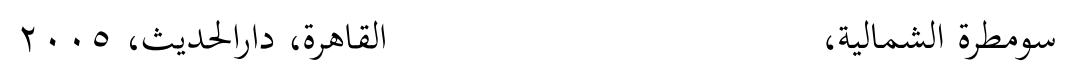

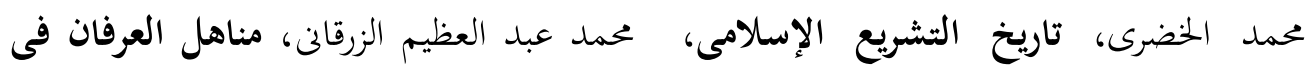

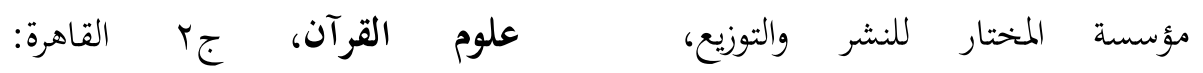

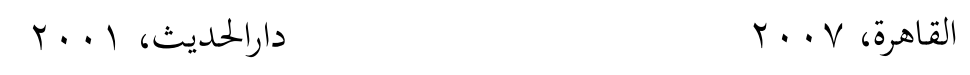

محمد الخطيب الشربيني، مغني المحتاج إلى موسى شاهين لاشين، فتح المنعم شرح

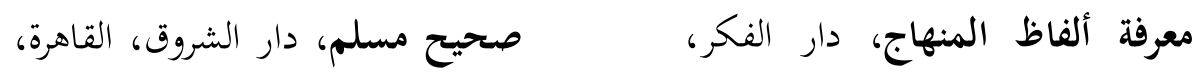
ج।
Pr. r t
بيروت ج 
Jurnal Ulunnuha Vol.7 No.2/Desember 2018 